\title{
FERMENTATION AND RECOVERY OF L-GLUTAMIC ACID FROM CASSAVA STARCH HYDROLYSATE BY ION-EXCHANGE RESIN COLUMN
}

\author{
K. Madhavan Nampoothiri'; Ashok Pandey ${ }^{1,2}$ * \\ ${ }^{1}$ Biotechnology Division, Regional Research Laboratory, CSIR, Trivandrum, India; ${ }^{2}$ Laboratório de \\ Processos Biotecnológicos, Departamento de Engenharia Quimica, Universidade Federal do Parana, \\ Curitiba, PR, Brasil
}

Submitted: November 03, 1998; Returned to authors for corrections: May 10, 1999; Approved: July 30, 1999

\begin{abstract}
Investigations were carried out with the aim of producing L-glutamic acid from Brevibacterium sp. by utilizing a locally available starchy substrate, cassava (Manihot esculenta Crantz). Initial studies were carried out in shake flasks, which showed that even though the yield was high with 85-90 DE (Dextrose Equivalent value), the maximum conversion yield ( $\sim 34 \%$ ) was obtained by using only partially digested starch hydrolysate, i.e. 45-50 DE. Fermentations were carried out in batch mode in a $5 \mathrm{~L}$ fermenter, using suitably diluted cassava starch hydrolysate, using a 85-90 DE value hydrolysate. Media supplemented with nutrients resulted in an accumulation of $21 \mathrm{~g} / \mathrm{L}$ glutamic acid with a fairly high $(66.3 \%)$ conversation yield of glucose to glutamic acid (based on glucose consumed and on $81.74 \%$ theoretical conversion rate). The bioreactor conditions most conducive for maximum production were $\mathrm{pH} 7.5$, temperature $30^{\circ} \mathrm{C}$ and an agitation of $180 \mathrm{rpm}$. When fermentation was conducted in fed-batch mode by keeping the residual reducing sugar concentration at $5 \% \mathrm{w} / \mathrm{v}, 25.0 \mathrm{~g} / \mathrm{L}$ of glutamate was obtained after $40 \mathrm{~h}$ fermentation ( $16 \%$ more the batch mode). Chromatographic separation by ion-exchange resin was used for the recovery and purification of glutamic acid. It was further crystallized and separated by making use of its low solubility at the isoelectric point ( $\mathrm{pH} 3.2)$.
\end{abstract}

Key words: Brevibacterium sp., L-glutamic acid, cassava hydrolysate, batch and fed-batch process, ion-exchange resin, purification

\section{INTRODUCTION}

L-amino acids have a wide spectrum of commercial use as food additives, feed supplements, infusion compounds, therapeutic agents and precursors for the synthesis of peptides or agrochemicals (14). Monosodium glutamate (MSG), the sodium salt of glutamic acid is used commercially as a flavour enhancer, usually in combination with nucleotides inosinate to provide an expansion and extension of taste in processed food such as soups, biscuits, noodles, Chines foods, meat and vegetable processing etc. (12). Glutamic acid mother liquor in MSG production is being used in the manufacture of Sauce and as soil conditioner, fertilizer etc. Several strains of Corynebacterium and Brevibacterium are used as cost effective bioconverters, which have been exploited by the fermentation industry to provide various amino acids, including L-glutamic $\operatorname{acid}(1)$.

Owing to the importance of the particular industrial fermentation, much efforts were still going

\footnotetext{
*Corresponding author. Mailing address: Present address: Laboratório de Processos Biotecnólogicos, Departamento de Engenharia Química, Universidade Federal do Paraná, CEP 81531-970, Curitiba, PR, Brasil. Fax:(+5541)266-0222.E-mail: ashok@engquim.ufpr.br
} 
on to improve the glutamic acid fermentation process especially from the standpoint of savings in production cost $(3,10)$. Cassava (Manihot esculenta Crantz) popularly known as tapioca, is one of the major tuber crops of the world, being cultivated extensively in tropical countries and obviously provides a major source of calories to millions of the people in the world. On dry weight basis, tapioca contains about $80-82 \%$ starch (fresh roots have about $22-30 \%$ starch) of which $55-60 \%$ is recoverable as starch. It is an excellent substrate for the reducing sugars such as (maltose, glucose etc), especially because of its ease of liquefaction.

The present study was undertaken with an aim to test the efficiency of cassava starch to be used as the substrate for L-glutamic acid production in batchand fed-batch processes. The optimized parameters in the fermentation using pure glucose (11) were applied to the cassava starch hydrolysate for the production of glutamic acid. Attempts were also made to isolate and purify the L-glutamic acid using chromatographic techniques with ion-exchange resin.

\section{MATERIALS AND METHODS}

\section{Microorganism and cultivation}

A strain of Brevibacterium sp. (DSM 20411) was used in the present study. The growth medium, culture preservation conditions and inoculum preparation were same as mentioned elsewhere (8).

\section{Preparation of cassava starch}

Fresh cassava tubers obtained locally were washed and peeled. The process of starch extraction from these tubers consisted of wet milling the washed cassava roots followed by washing the starch from the fibrous mass. Starch was sedimented in settling containers and air-dried.

\section{Hydrolysis of cassava starch}

Liquefaction of the starch slurries $(5 \%, \mathrm{w} / \mathrm{v})$ was carried out using a thermostable $\alpha$-amylase (Termamyl 120, Novo Industries, Bagsvared, Denmark) produced from a strain of Bacillus licheniformis. The enzyme was having $120 \mathrm{KNU} / \mathrm{g}$ activity (one Novo $\alpha$-amyl ase unit (NU) is defined as the amount of enzyme that hydrolyses $5.26 \mathrm{~g}$ $\mathrm{starch} / \mathrm{h}$ under Novo's standard conditions). The $\mathrm{pH}$ of the slurry was adjusted to 6.0 and reaction was carried out in a stirred reactor with enzyme at $85^{\circ} \mathrm{C}$ for $2 \mathrm{~h}$. The resulting solution was cooled to $60^{\circ} \mathrm{C}$ and after adjusting the $\mathrm{pH}$ 4.8-5.0 (with $1 \mathrm{~N} \mathrm{HCl}$ ), saccharification was carried out with a fungal glucoamylase (AMG 300, Novo industries, which has an activity of $300 \mathrm{AGU} / \mathrm{ml}$ ) (one Novo amyloglucosidase unit is defined as the amount of enzyme that splits one micromole of maltose per minute at $25^{\circ} \mathrm{C}$ ). Reaction was carried out for $18-24 \mathrm{~h}$ at $60^{\circ} \mathrm{C}$ and was then stopped by heating to $90^{\circ} \mathrm{C}$ for 10 minutes. The hydrolysate was double filtered using a nylon cloth and later by using Whatman $\mathrm{N}^{\circ} 1$ filter paper so as to get the clear hydrolysate. Hydrolysate of different dextrose equivalent (DE) values containing different concentrations of sugars were prepared by the analysis of hydrolysate at different time intervals for the reducing sugars.

\section{Fermentation}

Batch process in flasks. Initial studies were carried out by taking $50 \mathrm{ml}$ media in $250 \mathrm{ml}$ Erlenmeyer flasks to study the effect of starch hydrolysate with different DE values on the growth and activity of Brevibacterium sp. Media were prepared by taking hydrolysate of different $\mathrm{DE}$ values and supplemented with $\mathrm{NaNO}_{3} 0.7 \mathrm{~g}, \mathrm{KH}_{2} \mathrm{PO}_{4} 0.12 \mathrm{~g}$, $1 \mathrm{ml}$ mineral solution $\left(\mathrm{FeSO}_{4} \cdot 7 \mathrm{H}_{2} \mathrm{O}, \mathrm{MnSO}_{4}\right.$, $\mathrm{MgSO}_{4} \cdot 7 \mathrm{H}_{2} \mathrm{O}, \mathrm{ZnSO}_{4} \cdot 6 \mathrm{H}_{2} \mathrm{O}$ and $\mathrm{NaCI}$, each $1 \mathrm{mg}$ ), $100 \mu \mathrm{l}$ corn steep liquor and one drop of Tween 80 in $100 \mathrm{ml}$ starch hydrolysate $(\mathrm{pH}$ 7.2). After autoclaving, the media were inoculated with $5 \% \mathrm{v} / \mathrm{v}$ suspension $\left(10^{8}\right.$ cells $\left./ \mathrm{ml}\right)$ of $20 \mathrm{~h}$ old Brevibacterium sp. (9). The optimum parameters obtained in earlier studies were maintained throughout the period of fermentation such as $\mathrm{pH} 7.5$, temperature $30^{\circ} \mathrm{C}$, and agitation speed $180 \mathrm{rpm}$ (8-10). Samples were withdrawn as whole flask at desired time intervals for analysis. The results reported are the average of three sets of experiments.

Batch process in fermenter. Cassava starch hydrolysate (85-90 DE) was diluted to $5 \%$ initial sugar concentration and was supplemented with $\mathrm{NaNO}_{3} 0.7 \mathrm{~g}, \mathrm{KH}_{2} \mathrm{PO}_{4} 0.12 \mathrm{~g}, 1 \mathrm{ml}$ mineral solution $\left(\mathrm{FeSO}_{4} \cdot 7 \mathrm{H}_{2} \mathrm{O}, \mathrm{MnSO}_{4}, \mathrm{MgSO}_{4} \cdot 7 \mathrm{H}_{2} \mathrm{O}, \mathrm{ZnSO}_{4} \cdot 6 \mathrm{H}_{2} \mathrm{O}\right.$ and $\mathrm{NaCI}$, each $1 \mathrm{mg}$ ), $100 \mu \mathrm{l}$ corn steep liquor and one drop of Tween 80 in $100 \mathrm{ml}$ starch hydrolysate (pH 7.2). Fermentation was carried out with a 
working volume of $2.5 \mathrm{~L}$ in a $5 \mathrm{~L}$ fermenter (BIOFLO III, New Brunswick Scientific, Edison, N, J., USA). Dissolved oxygen was maintained at $60 \%$ of air saturated medium.

Fed-batch process in fermenter. Fed-batch process was also carried out in the fermenter. The initial concentration of reducing sugars in the medium was $5 \%$, and at the stages, where the concentration fell to $2 \%$ (as determined by the analysis of fermentation medium), starch hydrolyzate solution containing $10 \%$ reducing sugars, was added to bring the sugar concentration of fermenting medium as $5 \%$. Fermentation conditions were the same as for batch process.

\section{Filtration and Centrifugation of Broth}

Two batches, each consisting of $2.5 \mathrm{~L}$ fermented broth (obtained from batch fermentation in fermenter) was filtered using a microfiltration unit (Millipore, USA), fitted with a $50 \mathrm{~mm}$ membrane diameter with a pore size of $45 \mu \mathrm{m}$ under vacuum using a pump. Both the filtrates were combined and then centrifuged at $10,000 \mathrm{rpm}$ for 10 minutes to get the supernatant, which was then used for the recovery of the product.

\section{Preparation of Resin}

Spherical particles of cation exchange resin, Amberlite IR 120 (Hi-media) was used. Prior to use, the resin was pre-conditioned according to the method of Moore and Stein (6). The resin (100 g) was washed thoroughly two times with $4 \mathrm{~N} \mathrm{HCI}$. After two washes with distilled water, the resin was then washed with $2 \mathrm{~N} \mathrm{NaOH}$ until the filtrate was alkaline. The resulting material (sodium salt of the resin) was suspended in 3-times its volume of $1 \mathrm{~N} \mathrm{NaOH}$ and heated over a steam bath for $2 \mathrm{~h}$ with occasional mixing. The supernatant fluid was decanted after 30 minutes of settling and replaced with fresh hot $1 \mathrm{~N} \mathrm{NaOH}$. The procedure was repeated two times. The resin was filtered and washed with $2 \mathrm{~L}$ of distilled water to make it free of alkali. The resin was finally stored as the moist sodium salt.

\section{Packing the Column}

Resin (as above) was placed in a column $(3 \mathrm{~cm} \times 50 \mathrm{~cm})$ containing distilled water and filled upto $25 \mathrm{~cm}^{3}$. The excess water was removed using a siphon.

\section{Separation Process by Ion-Exchange Column}

The chromatographic conditions were selected to minimize the inhibitory effect of co-existing inorganic ions on the adsorption of amino acids by ion-exchange resins, following the method of Samejima (13). Removal of impurities from the broth was done by filtering and centrifuging the broth. The $\mathrm{pH}$ of the broth dropped from 7.5 to 4 with $1 \mathrm{~N} \mathrm{HCl}$, which was the most important factor affecting the adsorption of glutamic acid on the resin because the ionic forms vary with the $\mathrm{pH}$.

The processes involved in the column were adsorption and elution. In the adsorption process, the broth used was adjusted to a suitable $\mathrm{pH}$ of 1.8-2.0, using $1 \mathrm{~N} \mathrm{HCl}$ to charge the glutamic acid so that the ion exchange between the glutamic acid and the resin could occur. The broth was continuously recycled at a flow rate of $20 \mathrm{ml} /$ minute (retention time 50 minutes) until glutamic acid was fully adsorbed in the column, leaving other ions. In the elution process, the $\mathrm{pH}$ was increased to $3.8-4.0$ by treating the broth with urea and sodium hydroxide. This was done to release the glutamic acid bound on the resin by changing the glutamic acid charge.

\section{Crystallization}

After adsorption and elution, the eluent containing a high amount of glutamic acid was acidified to $\mathrm{pH} 3.2$, the isoelectric point of glutamic acid with $1 \mathrm{~N} \mathrm{HCl}$. Storage at $20^{\circ} \mathrm{C}$ for $48 \mathrm{~h}$ resulted in the formation of crystals of glutamic acid. After evaporation of the eluent, the dry solid crystals were obtained.

\section{Analytical Methods}

Bacterial growth was determined by measuring the optical density (OD) of the culture broth at 610 $\mathrm{nm}$ using an UV-visible spectrophotometer (UV-160 A Shimadzu, Japan). Total carbohydrates in the samples were detected by phenol-sulphuric-acid method (4). Starch content was determined by hydrolyzing the substrate with $10 \% \mathrm{HCl}$ and estimating the glucose content by DNS reagent (5). $\mathrm{pH}$ measurements were made by a standard $\mathrm{pH}$ meter (model $361 \mu$, Systronics, Ahmedabad, India). Thin layer chromatography (TLC) was used (Silica gel G, Solvent mixture-n butanol/glacial acetic acid/water $4: 1: 1, \mathrm{v} / \mathrm{v}$ ) for the qualitative detection of L-glutamic acid (2). The TLC plate with ninhydrin showed only 
one spot, which was identical with authentic sample of L-glutamic acid, hence ninhydrin colour reaction method was used for quantitative estimation of L-glutamic acid (15). Product purity was reconfirmed by IR-spectrum (Perkin Elmer Model 882) using pure L-glutamic acid as a standard (3).

\section{RESULTS AND DISCUSSION}

\section{Growth and glutamic acid production based on} the hydrolysate having different $D E$ values. Fig. 1 shows the growth pattern of Brevibacterium sp. on cassava starch hydrolysate. In general, higher DE hydrolysate supported better growth of the culture, which was maximum with the 85-90 DE hydrolysate (OD 1.92 at $18 \mathrm{~h}$ ). Apparently, the rate of cell growth was directly related with the DE values of the hydrolysate, as higher the DE value, lesser was the time to achieve maximum cell growth in hydrolysate of different DE values. In case of 15-20 DE hydrolysate, the growth was slowest and it took $30 \mathrm{~h}$ for the cells to achive the maximum growth.

Fig. 2 shows the consumption of reducing sugars by Brevibacterium sp. at different DE values. The pattern was similar in all cases with a consumption of more than $85 \%$ sugars (a maximum of $94 \%$ with DE $85-90)$. Fig. 3 shows the glutamate production at different time intervals. A maximum of $8.8 \mathrm{mg} / \mathrm{ml}$

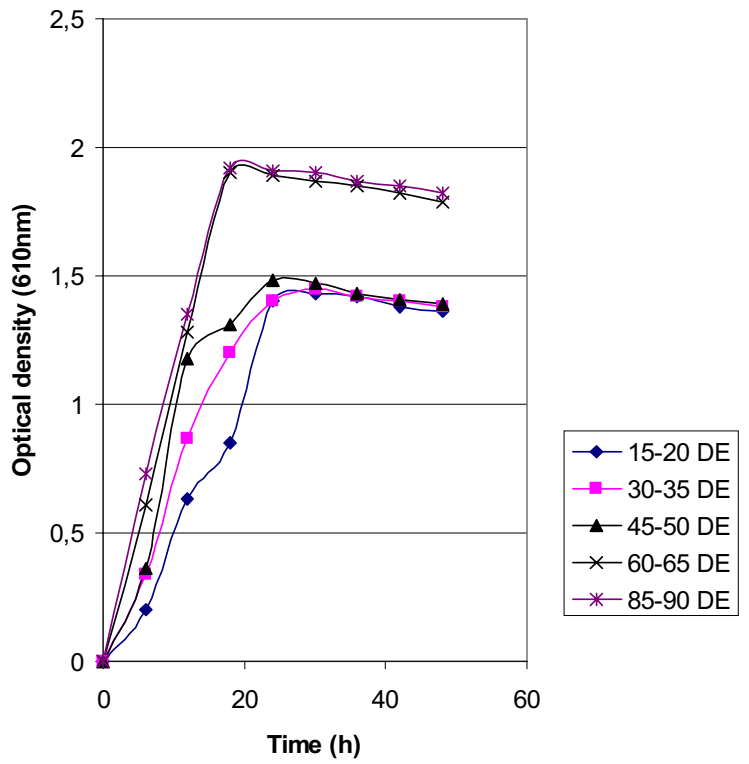

Figure 1 - Growth pattern of Brevibacterium sp. in cassava starch hydrolysate medium of different DE values.

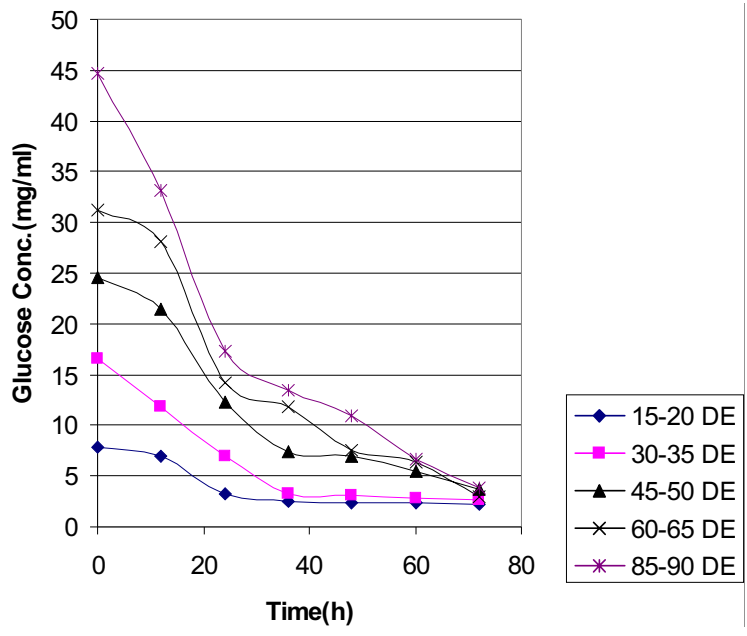

Figure 2 - Consumption of sugars by Brevibacterium sp. in different DE starch hydrolysate.

L-glutamic acid was obtained after $60 \mathrm{~h}$ fermentation with the medium having 85-90 DE. While considering the percentage conversion of sugars to L-glutamic acid (based on glucose consumed and $81.74 \%$ as the theoretical conversion rate) (8); it was maximum (34\%) with the hydrolysate having DE value 45-50 as shown in Fig. 4. On the other hand, with 85-90 DE hydrolysate, the conversion was lowest $(\sim 27 \%)$. Thus, if conversion factor has to be considered as a major criterion, a low DE value hydrolysate, i.e. 45-50 DE would be sufficient for L-glutamic acid production. There are reports in the literature where a wide variety of applications have been mentioned for low DE starch hydrolysate (7).

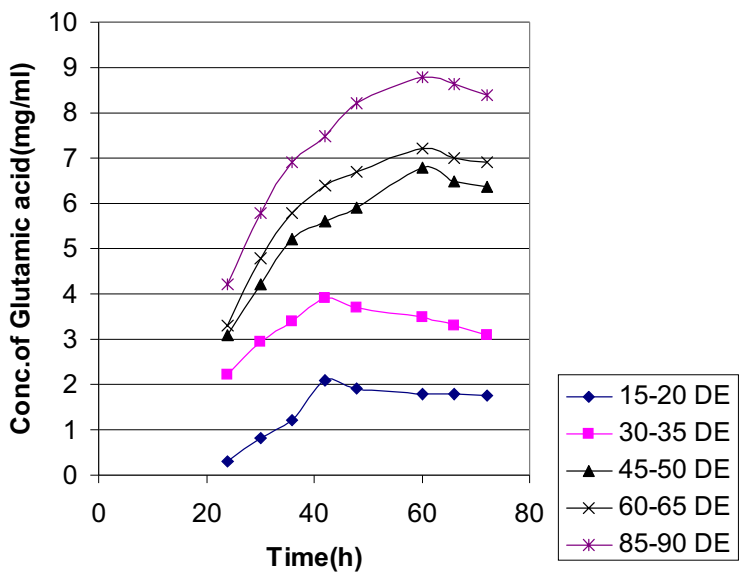

Figure 3 - Yields of L-glutamic acid by Brevibacterium s. in different DE value starch hydrolysate. 


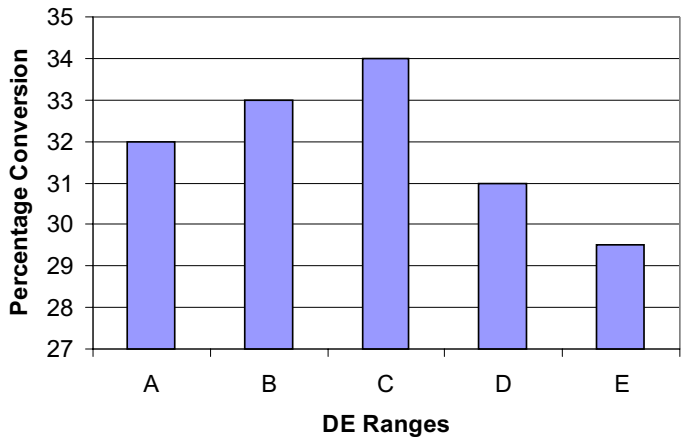

Figure 4 - Percentage conversion of cassava starch hydrolysate of L-glutamic acid.

In this context, our findings are significant. Yet, another advantage of partially hydrolyzed starch was that the glucose could be made available in a kind of controlled release process, which avoided the kind of repression, which normally one faces with fermentation feed stocks.

Studies in fermenter. Table 1 shows the summary of the fermentation process (batch mode) such as cell growth, substrate consumption and the corresponding product fermentation. From the data it was evident that more than $95 \%$ of the reducing sugars were consumed and within $40 \mathrm{~h}$ fermentation the accumulation of glutamic acid was nearly $21 \mathrm{~g} / \mathrm{L}$, which was approximately two and half fold more than what was obtained in shake flask studies. Based on the glucose consumed and also by assuming $81.7 \%$ as the theoretical conversion, we got conversion of about $66.3 \%$.

Fig. 5 shows a comparison of bacterial growth and L-glutamic acid production in batch and fed-batch process. A maximum of $25 \mathrm{~g} / \mathrm{L}$ of glutamate was obtained in fed-batch process, which was $16 \%$ more than the batch mode. Hence, the maintenance of an active biomass constantly for a long period could

Table 1 - The overall changes during L-glutamic acid fermentation (in $5 \mathrm{~L}$ fermenter) using Brevibacterium sp.

\begin{tabular}{cccc}
\hline Time & Optical density & $\begin{array}{c}\text { Conc. Of } \\
\text { glutamic acid } \\
(\mathrm{mg} / \mathrm{ml})\end{array}$ & $\begin{array}{c}\text { Glucose } \\
\text { consumption } \\
(\%)\end{array}$ \\
\hline 12 & 1.65 & 4.15 & 21.84 \\
24 & 2.12 & 8.35 & 42.64 \\
36 & 2.07 & 4.70 & 89.78 \\
48 & 1.98 & 25.20 & 92.73 \\
60 & 1.95 & 25.14 & 93.10 \\
\hline
\end{tabular}

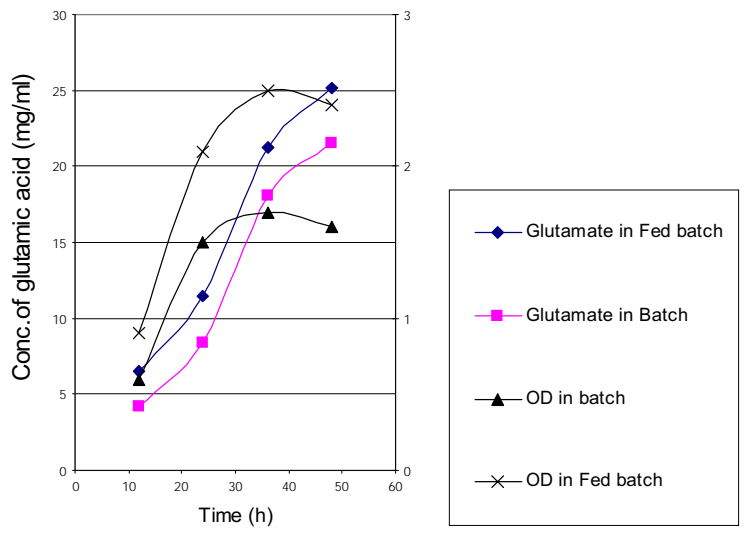

Figure 5 - Comparison of the growth profile and glutamic acid production in batch and fed batch processes.

enhance the accumulation of glutamate to a certain extent only.

Recovery of glutamic acid. The fermented broth contained various impurities such as bacterial cells, macromolecules, pigments, inorganic substances, organic substances etc., which were removed by filtration and centrifugation. Glutamic acid was purified from cation exchange resin. The elution profiles of the glutamic acid concentration from the column are shows in Fig. 6. Symmetrical peaks of glutamic acid concentration and absorbance were obtained. Glutamic acid was recovered for the highest

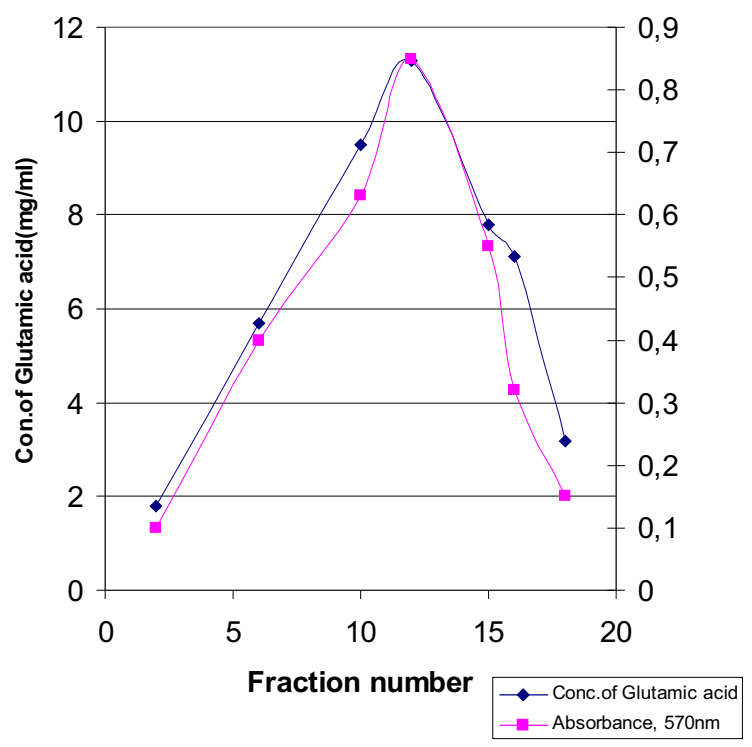

Figure 6 - Glutamic acid recovered at different elution volumes through ion-exchange resin column. 
yield, taking the fractions of 8 to 17 (total elution volume of $200 \mathrm{ml}$ ) through the ion-exchange column. By changing the $\mathrm{pH}$ to the isoelectric point (3.2) and by the subsequent cooling of the eluent, glutamic acid was crystallized out. The purity of the final product, which was reconfirmed using IR spectrum, showed similar peak at the same frequencies. All functional groups of the product $\left(\mathrm{NH}_{2} \mathrm{COOH}\right.$, and $\left.\mathrm{CH}_{2}\right)$ showed a frequency similar to standard glutamic acid as shown in Fig. 7.

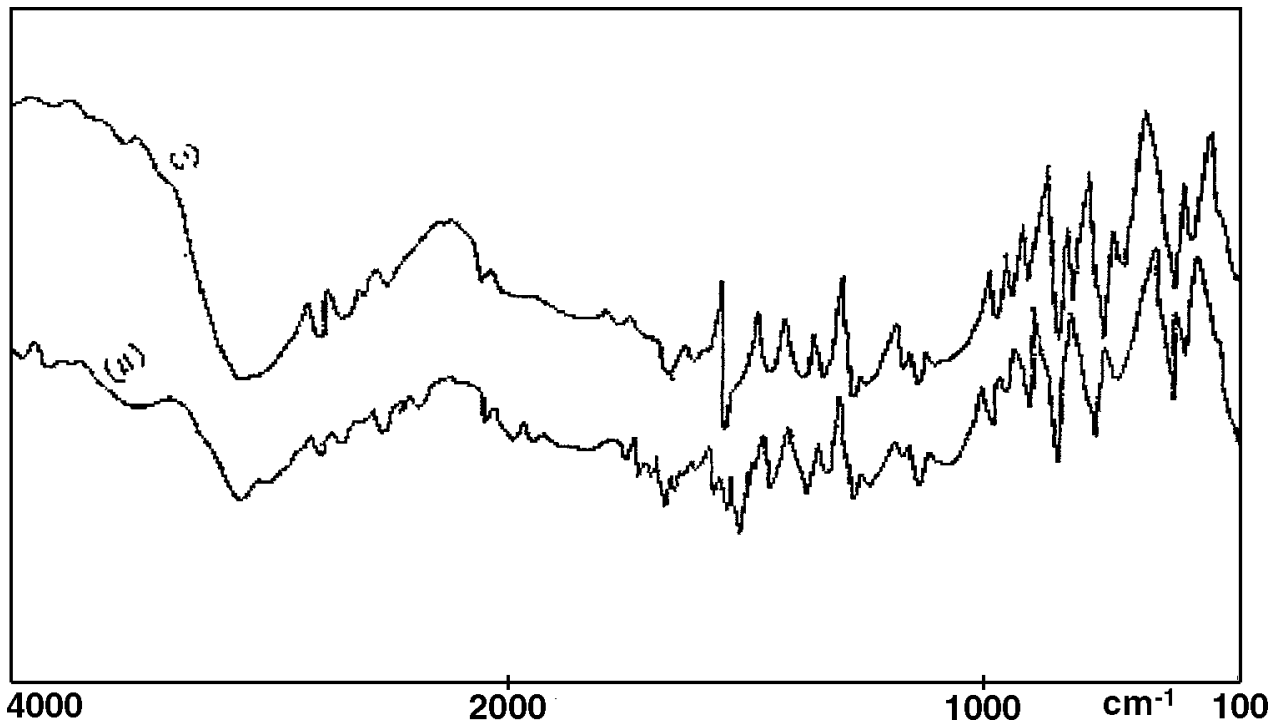

Figure 7 - IR-spectra of standard (1) and purified (II) samples of L-glutamic acid.

\section{CONCLUSIONS}

The results of the present study have indicated the possibility of utilizing starchy tubers as a raw material for L-glutamic acid production. It further indicated that as a soluble non-sweet, easily digestible carbohydrates, the low DE starch hydrolysate could find a potent industrial application (as a low cost raw material for amino acid fermentation). By making use of various combinations of environmental factors, ion-exchange resins could effectively be utilized for concentration and separation of glutamic acid.

\section{ACKNOWLEDGEMENTS}

KMN is grateful to the Council of Scientific and Industrial Research, New Delhi, for the award of a Senior Research Fellowship. We thank Ms. Luziana. P. S. Vandenberghe, UFPR for helping to prepare Portuguese Resumo of the manuscript.

\section{RESUMO}

\section{Produção de ácido L-glutâmico a partir de um hidrolisado de amido de mandioca usando resina de troca iônica}

Pesquisas foram realizadas com o objetivo de produzir ácido glutâmico a partir de Brevibacterium sp. utilizando um substrato disponível na região, a mandioca (Manihot esculenta Crantz). Estudos iniciais, desenvolvidos em shaker, demonstraram que mesmo obtendo elevado rendimento com 85-90 DE (Dextrose Equivalent value), a taxa de conversão máxima $(\sim 34 \%)$ foi obtida usando um hidrolisado de amido parcialmente digerido, i.e. 45-50 DE. As fermentações foram realizadas em um fermentador de $5 \mathrm{~L}$, usando um hidrolisado de amido de mandioca adequadamente diluído, preparado à partir de um valor DE de 85-90. O meio enriquecido com nutrientes resultou em um acúmulo de $21 \mathrm{~g} / \mathrm{L}$ de ácido glutâmico, com uma elevada $(66,3 \%)$ taxa de 
conversão da glicose em ácido glutâmico (baseada em glicose consumida e em uma taxa de conversão teórica de $81,74 \%$ ). As condições mais favoráveis, levando à uma máxima produção, foram $\mathrm{pH}$ 7.5, temperatura $30^{\circ} \mathrm{C}$ e agitação de $180 \mathrm{rpm}$. Quando a fermentação foi conduzida em um reator do tipo descontinuo alimentado, onde a concentração de açúcares redutores era mantida em $5 \% \mathrm{w} / \mathrm{v}$, foram obtidos $25.0 \mathrm{~g} / \mathrm{L}$ de glutamato após $40 \mathrm{~h}$ (16\% a mais do que no modo descontinuo). Para a recuperação e purificação do ácido glutâmico, foi utilizada a separação por cromatografia com resina de troca inônica. O ácido foi posteriormente cristalizado e separado, levando-se em consideração a sua baixa solubilidade no ponto isoelétrico ( $\mathrm{pH} 3.2)$.

Palavras-chave: Brevibacterium sp, L-ácido glutâmico, hidrolisado de mandioca, processo batch e fed-batch, resina de troca iônica, purificação

\section{REFERENCES}

1. Aida, K.; Chibata, L.; Nakayama, K.; Takinami, K.; Yamada, K. (eds.) Biotechnology of amino acid production, Elsevier, Amsterdam, 1986.

2. Brenner, M.; Neiderwiser, A. Thin layer chromatography (TLC) of amino acids. In: C.H.W. Hirs (ed.) Methods of Enzymology, Vol. XI, Academic Press, New York 1967, p. 39-59.
3. Das, K.; Anis, M.; Azemi, B.N.N.; Ismail, P. Fermentation and recovery of glutamic acid from palm waste hydrolysate by ion-exchange resin column. Biotechnol. Bioeng. 48: 551-555, 1995.

4. Dubois, M.; Gilles, K.A.; Hamilton, J.K.; Rebers, P.A.; Smith, F. Phenol sulfuric acid method for the determination of total carbohydrates. Anal. Chem. 28: 350-356, 1956

5. Miller, G.L. Use of dinitrosalicylic acid reagent for determination of reducing sugars. Anal. Chem. 31: 426-428, 1959.

6. Moore, S.; Stein, N.H. Chromatography of amino acids on sulfonated polystyrene resins. J. Biol. Chem. 192: 66, 1951.

7. Murray, D.G.; Luff, L.R.; Low, D.E. Corn starch hydrolysates, Multifunctional carbohydrate acid in food formation. Food Technol. 27: 32, 1973.

8. Nampoothiri, K.M.; Pandey, A. Effect of different carbon sources on growth and glutamic acid fermentation by Brevibacterium sp. J. Basic Microbiol. 35: 249-254, 1995.

9. Nampoothiri, K.M.; Pandey, A. Glutamic acid fermentation using Brevibacterium DSM 20411. J. Food Sci. Technol. 32: 406-408, 1995.

10. Nampoothiri, K.M.; Pandey, A. Solid State Fermentation for L-glutamic acid production using Brevibacterium sp. Biotech. Letts. 18: 199-204, 1996.

11. Nampoothiri, K.M.; Pandey, A. Unease activity in a glutamate producing Brevibacterium sp. Process Biochem. 31: 471-475, 1996.

12. Nampoothiri, K.M.; Pandey, A. Genetic tuning of coryneform bacteria for the overproduction of amino acids. Process Biochem. 33: 147-61,1998.

13. Samejima, H. Extraction and purification of amino acids. In: K. Yamada; S. Kinoshita; T. Tsunoda; K. Aida (eds.), Microbial production of amino acids, Kodonsho, Tokyo, 